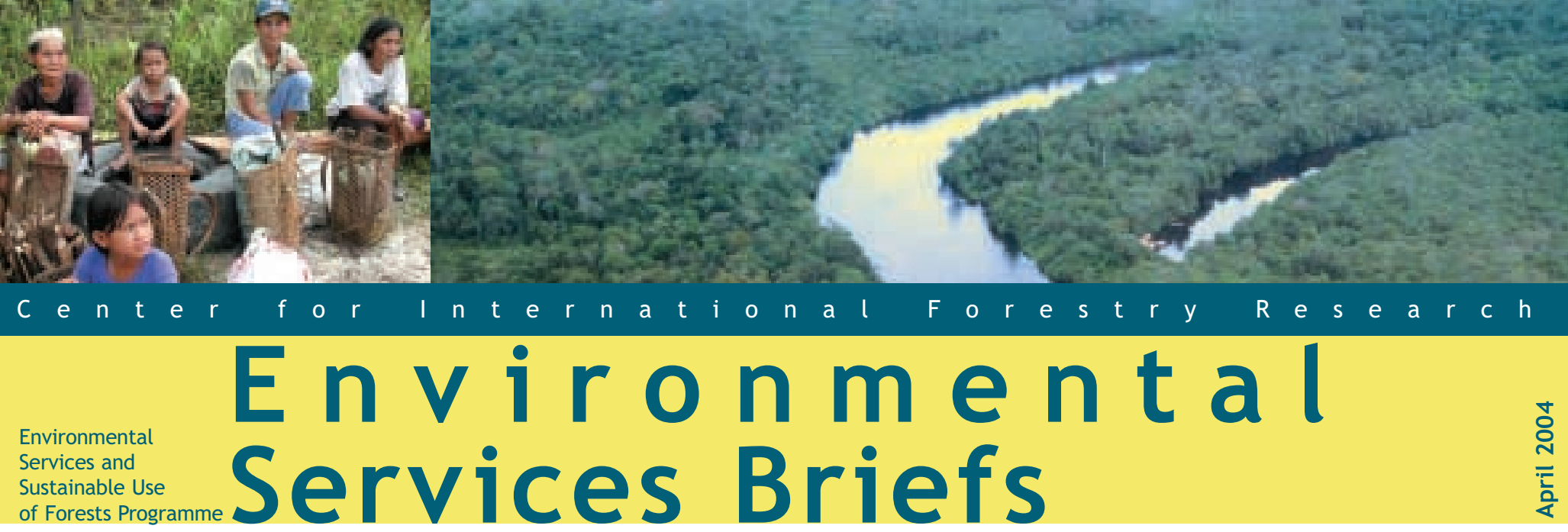

\title{
Prioritas Masyarakat Lokal dalam Pengelolaan Sumberdaya Lahan Hutan di Hulu Sungai Malinau, Kalimantan Timur
}

Oleh: Imam Basuki dan Douglas Sheil

Penggunaan lahan apa yang secara ekonomi dan lingkungan dapat dikembangkan di hulu Sungai Malinau? Wilayah mana yang berpotensi untuk pengembangan tanaman perkebunan? Lokasi-lokasi apa yang penting bagi masyarakat lokal? Artikel ini merupakan ringkasan tentang apa saja yang telah diperoleh CIFOR (center for international forestry research/lembaga penelitian kehutanan internasional), Bogor, dari penelitian lahan yang telah dilakukan di Kabupaten Malinau, Kalimantan Timur.

Persepsi masyarakat lokal dalam pengelolaan sumberdaya lahan, sering kali sulit dipahami oleh berbagai pihak diluar masyarakat tersebut. Hal ini dapat menyebabkan adanya kegiatan-kegiatan pembangunan yang tidak didukung oleh masyarakat, timbulnya konflik diantara berbagai pihak atau tidak dapat dirasakan manfaatnya. Berangkat dari fakta tersebut, maka diperlukan informasi untuk meningkatkan pemahaman tentang persepsi masyarakat lokal terhadap sumberdaya lahan (tanah, vegetasi dan manfaatnya), dan untuk mencegah dampak negatif pembangunan yang tidak perlu terjadi. Melalui pemahaman yang lebih baik, diharapkan prioritas pembangunan dan pengelolaan wilayah di masa depan lebih sesuai dengan prioritas dan kebutuhan masyarakat lokal.

Malinau diketahui oleh pihak luar memiliki beragam formasi geologi, tetapi belum banyak yang mengetahui mengenai sumberdaya lahan berikut potensi penggunaan dan persepsi masyarakat lokal tentang sumberdaya tersebut. Pemerintah daerah Malinau selama ini telah berupaya untuk meningkatkan pembangunannya terutama di bidang pemanfaatan sumberdaya alam. Kami dari CIFOR berupaya untuk mendukung upaya Pemda tersebut, dengan melakukan studi yang mengungkapkan keadaan sumberdaya lahan, bersama tujuh kelompok masyarakat di sekitar hulu Sungai Malinau, sejak tahun 1999 hingga 2001. Metode penelitian yang kami gunakan (Multidisciplinary Landscape Assessment/MLA) menggunakan pendekatan berbagai aspek termasuk keanekaragaman hayati, biofisik lahan, dan sosial. Informasi lebih rinci dan beberapa hasil studi telah dan akan dipublikasikan (lihat daftar pustaka di bawah: Sheil et al. 2003; Sheil et al. 2003a,b).

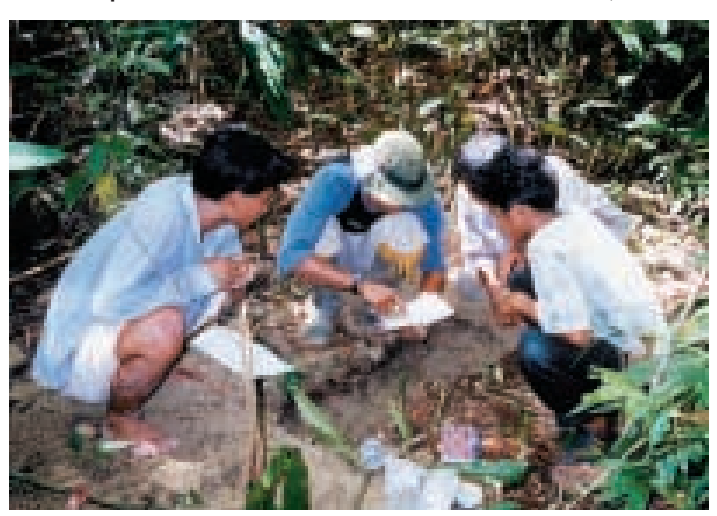

Enam ratus contoh tanah yang diambil dari 200 plot penelitian telah dianalisa dan dipelajari. Disamping itu, persepsi masyarakat lokal mengenai sumberdaya lahannya untuk setiap plot juga telah dicatat melalui kerjasama dengan informan lokal (Gambar 1). Mereka berasal dari Suku Merap yang kebanyakan beraktivitas sebagai peladang gilir balik dan Suku Punan yang mayoritas memanfaatkan hasilhasil hutan.

Gambar 1. Kerjasama CIFOR dengan masyarakat setempat dalam penelitian lahan dan tanah di hulu sungai Malinau. (Foto : Douglas Sheil) 


\section{Tanah dan Evaluasi Lahan}

Tanah-tanah yang kami temui di lokasi yang dimanfaatkan oleh masyarakat desa, kondisinya bervariasi dalam hal kimia, fisik dan biologis; tetapi semua memiliki kesuburan yang relatif rendah (Staf peneliti, 1983). Ketidaksuburan ini dicirikan dengan kemasaman tanah $(p H)$, dan rendahnya kemampuan menyediakan zat hara bagi tanaman (Kapasitas Tukar Kation), dan bahan organik. Secara umum tingkat ancaman erosi terhadap tanah sangat tinggi karena topografi yang curam di wilayah hulu (>30\%) sehingga dalam hutan primerpun telah terjadi erosi (Gambar 2). Tanah pada beberapa tempat penebangan kayu (logging) terbukti lebih padat. Hal ini akan mempercepat proses erosi dan memperlambat proses penghutanan kembali. Padas yang keras ditemukan pada banyak plot (di permukaan hingga kedalaman $60 \mathrm{~cm}$; teramati pada sepertiga jumlah total plot) dan semakin mengurangi alternatif penggunaan lahan non-hutan. Secara umum lahan hutan di hulu Sungai Malinau tidak sesuai untuk diubah menjadi lahan perkebunan yang intensif tanpa dukungan teknologi tinggi dan biaya yang sangat besar.

Kami telah mengevaluasi kesesuaian lahan untuk pengembangan beberapa tanaman pertanian dan perkebunan menggunakan kriteria baku dari Departemen Pertanian Indonesia (Bina Program, 1997). Evaluasi ini dilakukan dengan anggapan yaitu bahwa penggunaan lahan dilakukan dalam skala besar, tanpa pupuk dan tanpa masa bera. Hasil evaluasi lahan dari semua plot menunjukkan bahwa potensi penggunaan lahan untuk pertanian dan perkebunan yang intensif dan berkelanjutan terdapat pada beberapa wilayah, yang relatif subur, di tepi sungai (sangat terbatas luasannya dan sangat potensial untuk terkena banjir). Lahan-lahan tersebut sesuai untuk pengembangan padi ladang dan kelapa (dengan penambahan abu sisa tanaman), namun tidak untuk lada, kopi, coklat, kemiri, karet, dan kelapa sawit.

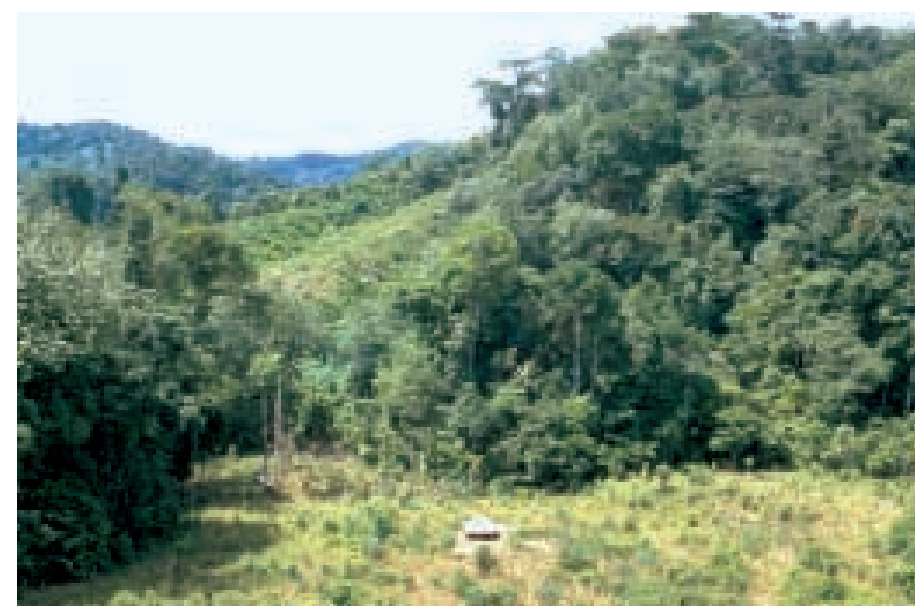

Sifat-sifat lahan setempat seperti bahaya erosi, kecuraman lereng, dangkalnya tanah, drainase yang sangat cepat, dan besarnya curah hujan merupakan faktor-faktor yang membatasi pengembangan perkebunan besar di luar wilayah dataran tepi sungai (Tabel 1). Dalam hal penggunaan yang intensif dan berkelanjutan, tanah-tanah yang paling tidak potensial adalah tanah tipis di lereng curam dan tanah berawa yang berpasir putih. Vegetasi alami yang berperan dalam mencegah tanah longsor dan menyediakan bahan-bahan hasil hutan bagi masyarakat di lokasilokasi tersebut perlu dilindungi fungsinya (misalnya pohon jelutung, damar dan meranti). Pertimbangan akan kondisi umum di hulu Sungai Malinau, keterbatasan wilayah ini tentunya juga sangat berhubungan dengan tingkat kepadatan penduduk yang rendah dan pilihan masyarakat lokal dalam mengembangkan sistem perladangan berpindah.

Tabel 1. Jumlah lokasi penelitian untuk tiap kelas kesesuaian lahan berdasarkan jenis tanaman (total = 200 lokasi) di hulu sungai Malinau. (Evaluasi menggunakan metode baku; Bina Program, 1997)

$\begin{array}{lccc}\text { Tanaman } & \text { Sangat sesuai } & \text { Sesuai marginal Tidak sesuai } \\ \text { Padi Ladang } & 4 & 11 & 185 \\ \text { Kelapa } & - & 63 & 137 \\ \text { Sawit } & - & - & 200 \\ \text { Lada } & - & - & 200 \\ \text { Coklat } & - & - & 200 \\ \text { Kopi } & - & - & 200 \\ \text { Kacang } & - & - & 200 \\ \text { Kemiri } & - & - & 200 \\ \text { Karet } & - & - & 200\end{array}$

Berdasarkan hasil evaluasi lahan untuk padi ladang kami coba membuat model sederhana untuk memperkirakan potensi lahan di tempat yang lain. Jarak suatu lokasi ke sungai terdekat dan ketinggiannya dari permukaan laut dijadikan sebagai faktor-faktor penduga kesesuaian lokasi untuk padi ladang. Seratus sembilan puluh delapan plot penelitian digunakan sebagai dasar dalam analisis yang menggunakan program ArcGIS (versi 8.3, 2002). Walau masih diliputi berbagai keterbatasan, peta kesesuaian lahan padi ladang tersebut menunjukkan bahwa sebagian besar wilayah yang paling berpotensi berada di daerah hilir dan tepian Sungai Malinau (Gambar 3).

Wilayah-wilayah potensial untuk pertanian yang ada sebaiknya dikembangkan seoptimal mungkin untuk memenuhi kebutuhan pangan masyarakat. Wilayah potensial yang umumnya mudah diakses melalui jalan darat atau sungai tersebut perlu diperhatikan agar manfaatnya dapat dirasakan oleh seluruh masyarakat, misalnya 


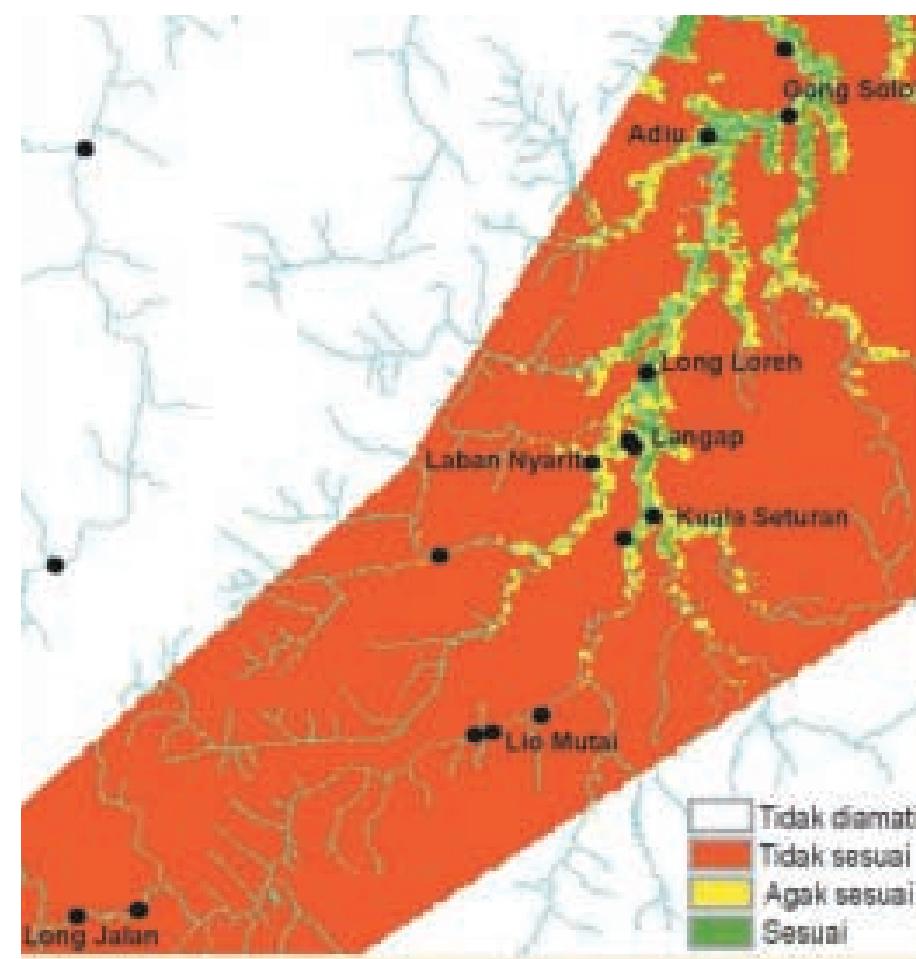

Gambar 3. Peta kesesuaian lahan untuk padi ladang di hulu Sungai Malinau. (Peta : Agus Salim dan Andy Darmawan)

dengan pengembangan sistem pertanian yang lebih intensif dan berkelanjutan, yang menggunakan pupuk dan bibit unggul. Sawah mungkin berpotensi untuk dikembangkan pada beberapa wilayah yang ketersediaan airnya terjamin dan pembuangan-air tanahnya memungkinkan. Namun banyaknya tenaga kerja dan waktu yang dibutuhkan untuk membangun dan memelihara sawah harus diperhitungkan mengingat keterbatasan tenaga kerja. Penggunaan kompos akan sangat membantu peningkatan produksi pertanian, hanya sekali lagi hal ini juga akan membutuhkan kerja keras untuk pembuatan dan penggunaannya.

Wilayah yang tidak potensial untuk pengembangan pertanian dan perkebunan yang intensif di Malinau, dapat dimanfaatkan untuk wanatani (sistem pertanian/perkebunan kehutanan) dengan pengembangan jenis tanaman lokal yang berharga seperti rotan atau damar, penebangan kayu hutan berdampak rendah (hutan produksi) dan konservasi alam sebagai alternatif penggunaan lahannya. Satu pengalaman dari daerah lain yang berhasil mengembangkan pola penggunaan lahan berbasis kehutanan adalah Lampung dalam pengembangan wanatani damar (lihat daftar pustaka di bawah: ICRAF 2002). Tata ruang dan peraturannya perlu dibuat, dengan melibatkan pihak yang kompeten dan berwawasan jangka panjang, untuk menghasilkan penggunaan lahan yang produktif, ekonomis, ditaati dan berkelanjutan.

\section{Persepsi Masyarakat}

Meskipun menghuni wilayah yang bertopografi curam ternyata persepsi masyarakat menunjukkan eratnya ketergantungan dan hubungan masyarakat dengan lahannya. Berbagai wawancara dengan masyarakat Merap dan Punan memberikan kejelasan bahwa mereka dapat mengevaluasi kualitas lahan untuk berladang dengan mengamati kondisi vegetasi dan warna tanah. Tana tiem, atau tanah hitam, diyakini oleh masyarakat Merap sebagai tanah yang paling subur dan produktif untuk pertanian. Tanah-tanah yang produktif, menurut persepsi masyarakat, sebagian besar ditemukan pada dataran aluvial dan masih ditutupi hutan. Sementara tanah yang tidak subur berada di daerah berawa atau lereng yang curam (Gambar 4). Masyarakat memanfaatkan semua lahan yang subur dan sedikit lahan yang tidak subur untuk menanam padi, buah dan sayursayuran, sementara sebagian besar lahan yang tidak subur dibiarkan sebagai hutan oleh masyarakat.

Perbedaan persepsi tentang tanah terdapat baik di dalam suatu kelompok masyarakat (suku) maupun di antara suku yang hidup di wilayah yang menjadi daerah penelitian ini. Hal ini dipengaruhi oleh pengalaman dalam menggunakan lahan dan nilai-nilai budaya tertentu. Masyarakat Merap secara umum menunjukkan pengetahuan dan evaluasi yang relatif lebih lengkap tentang tanah dibandingkan masyarakat Punan. Lebih jauh, informasi yang diberikan oleh informan Merap juga memiliki hubungan yang lebih kuat dengan hasil pengukuran kami tentang kesuburan tanah.

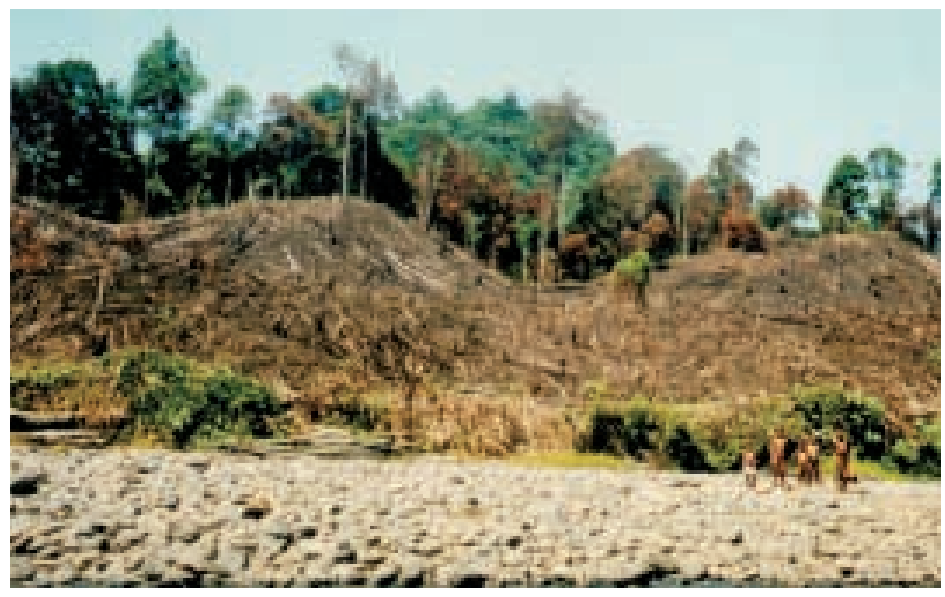

Gambar 4. Beberapa lokasi yang tidak subur sebagian masih dimanfaatkan oleh masyarakat untuk berladang. (Foto: Douglas Sheil)

\section{Kesimpulan}

Dua kesimpulan utama yang dapat kami sampaikan berdasarkan hasil penelitian ini adalah: 1) terbatasnya kemungkinan pengembangan kegiatan di luar sektor kehutanan di wilayah hulu Sungai Malinau, dan 2) masyarakat dengan pengetahuan 
lokalnya merupakan para ahli yang mampu mencukupi kebutuhan hidup sehari-hari dengan memanfaatkan sumberdaya alam di sekitarnya. Sebagai ilustrasi dari kesimpulan pertama, kami memberikan fakta bahwa 200 lokasi contoh yang diteliti, tidak berpotensi untuk pengembangan tanaman perkebunan seperti kelapa sawit, lada dan kopi (dalam skala besar, tanpa masa bera dan tanpa pupuk). Kami dapat memahami bahwa hal ini adalah pengaruh nyata dari kondisi wilayah yang bertanah tidak subur dan terjal. Pengembangan pertanian dan perkebunan yang intensif lebih baik difokuskan pada wilayah hilir Sungai Malinau, yang relatif datar dan lebih subur. Wilayah hulu akan lebih produktif dan lestari bila dikembangkan untuk hutan produksi dan wanatani. Kesimpulan kedua dapat dijabarkan bahwa masyarakat telah mampu bertahan hidup dengan aktivitas perladangan gilir balik yang berskala kecil walau hanya menggunakan lahan yang tidak subur. Pada kondisi demikian tampaknya perladangan gilir balik dengan penduduk yang sedikit merupakan sebuah sistem produksi yang rasional dan cocok. Tentu rendahnya tingkat kepadatan penduduk di wilayah ini sangat berhubungan dengan ketidaksuburan lahannya.

Pemahaman yang telah kami dapatkan tentang keterbatasan kondisi tanah di hulu Sungai Malinau dan nilai pentingnya bagi masyarakat setempat, memberikan dasar yang sangat penting untuk pengelolaan lahan dan hutan di masa datang. Pilihan masyarakat lokal merupakan sebuah bagian penting dalam usaha untuk mewujudkan pengelolaan sumberdaya lahan dan hutan di daerah Malinau yang efektif dan berkelanjutan, yang salah satu pelaksanaannya adalah dengan tidak mengganggu lokasi yang sangat dilindungi oleh masyarakat lokal (misalnya kuburan). Hasil penelitian CIFOR, sejalan dengan visi pembangunan kehutanan dari Pemda Malinau (Sekda Malinau dalam diskusi mengenai Rencana Tata Ruang dengan CIFOR tahun 2002), menunjukkan potensi wilayah hutannya untuk dikembangkan menjadi daerah pertanian/ perkebunan hutan (wanatani), ekowisata, pengolahan kayu dan atau konservasi alam (lihat daftar pustaka di bawah: CIFOR 2002). Pertanian hutan yang berkelanjutan, masa depan hutan, dan kesejahteraan penduduk tergantung pada pengelolaan yang bijaksana; dan memperhatikan pengetahuan dan kepentingan masyarakat lokal; serta memperhitungkan keterbatasan yang ada dari tanah dan lahan.

\section{Pustaka}

Basuki, I., and Sheil, D., 2004. Local Perspectives of Forest Landscapes: A Preliminary Evaluation of Land, Soil, and Importance, in Malinau, East Kalimantan, Indonesia. CIFOR. (in prep.)

Bina Program, 1997. Kriteria Evaluasi Kesesuaian Lahan. Departemen Pertanian, Indonesia.

CIFOR, 2002. Memelihara Hutan Malinau Pada Masa Kini dan Masa Depan : Beberapa Pandangan untuk Rencana Tata Ruang 2002 Kabupaten Malinau.

Sheil, et al. 2002. Exploring biological diversity, environment and local people's perspectives in forest landscapes. Methods for a multidisciplinary landscape assessment. Center for International Forestry Research. Bogor. Indonesia.

Sheil, et al. 2003a. Local priorities and biodiversity in tropical forest landscapes: asking people what matters. Tropical Forest Update. 13:1

Sheil, et al. 2003b. Prioritas lokal dan keanekaragaman hayati dalam lansekap hutan: apa yang penting menurut masyarakat? Jurnal Hutan Indonesia (Indonesia Forest Journal). Edisi Agustus 2003.

Staf Peneliti, 1983. Terms of Reference Klasifikasi Kesesuaian Lahan. Pusat Penelitian Tanah. Proyek Penelitian Pertanian Menunjang Transmigrasi (P3MT). Departemen Pertanian.
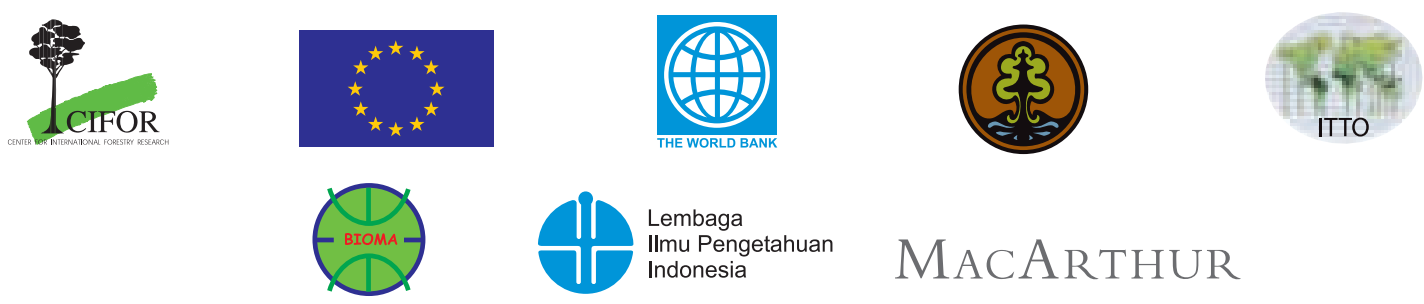

Lembaga

Environmental Services and Sustainable Use of Forests, CIFOR

office: Jalan CIFOR, Situ Gede, Sindang Barang

Bogor Barat 16680, Indonesia. mailing: P.O. Box. 6596 JKPWB, Jakarta 10065, Indonesia Tel: +62(251) 622622 Fax: +62(251) 622100 E-mail: cifor@cgiar.org Website: www.cifor.cgiar.org 